\title{
Psychological pain management
}

\author{
- a review of German clinical psychology related to \\ patients suffering from rheumatic diseases ${ }^{1)}$ \\ O. Berndt Scholz \\ Psychologisches Institut der Universität Bonn \\ Römerstraße 164 D-5300 Bonn 1 Germany \\ Aiko Satow \\ Hamamatsu Univesity School of Medicine, \\ 3600 Handa-cho, Hamamatsu 431-31, Japan
}

\begin{abstract}
An overview of the behavioral medical strategies used by psychologists in German speaking countries is presented and exemplified by the work with patients suffering from rheumatoid arthritis. Introducing epidemiologic data, the necessity of qualified patients information and education about their diagnosis, course, prognosis and therapeutic strategies are highlighted. Seven different strategies of psychological therapy are described and classified, and their efficiency for pain reduction is discussed. A comprehensive pain therapeutic program, developed by Rehfisch et al. (1988) is presented which consists of 12 structured but individually-tailored sessions. Some evaluative results of that program are given.
\end{abstract}

\section{Introduction}

Rheumatic diseases are common in Germany. It is estimated that there are more than 2 million patients (or 3 percent of the population) presently suffering from rheumatic diseases in former West Germany. Likewise $69 \%$ of all German people between the age of 15 and 64 years will have rheumatism at any point in time. Between 10 and $20 \%$ of all disabled employees suffer from rheumatic diseases. These rates are much smaller in Japan. In 1983, there were about 172,000 treated cases of rheumatic diseases in Germany which were paid for by the official health insurance (Verband
Deutscher Rentenversicherungsträger, 1984). That means that the number of treated rheumatic disease patients is 2.3 times higher than the number of patients treated for classical psychiatric diseases in former West Germany. Thus, rheumatic diseases are a substantial health problem in Germany.

Likewise, one should remember that the prognoses of the rheumatic diseases are not good. Rheumatoid arthritis (RA), spondylitis ancylosans and also Fibromyalgia, to name the most disseminated rheumatic syndromes, are chronical diseases which are characterized by almost unknown etiology, limited therapeutic

1) Modified version of lecture given by the first author at Hamamatsu University, School of Medicine, on $9-12-91$.

- Received January 31, 1992 ; accepted June 12, 1992 
possibilities, irreversible pathology and also numerous secondary and tertiary (negative) aftereffects.

The epidemiology and nosology of the rheumatic diseases, especially RA, is such that further investigation of the psychosocial conditions of rheumatic syndrome is warranted (Raspe, 1989).

Table 1 Focuses of rheumatoid arthritis (from: Raspe, 1989)

\begin{tabular}{ll} 
SCOPE & \multicolumn{1}{c}{ EXAMPLES } \\
\hline Somatic & $\begin{array}{l}\text { Pain } \\
\text { Inability to perform bodily } \\
\text { functions } \\
\text { Obstructions }\end{array}$ \\
\hline Experience & $\begin{array}{l}\text { Self-doubts, Insecurity } \\
\text { Reduced bodily self perception } \\
\text { offence } \\
\text { Depression, feelings of isolation } \\
\text { Anxiety, worries } \\
\text { Anger (anger-in; anger-out) }\end{array}$ \\
\hline Behavior & $\begin{array}{l}\text { Difficulties in: } \\
\text { daily life } \\
\text { emotional expressiveness } \\
\text { social contacts }\end{array}$ \\
& $\begin{array}{l}\text { Disease-behavior } \\
\text { Pain-behavior }\end{array}$ \\
\hline Family/Partnership & $\begin{array}{l}\text { Fanily climate } \\
\text { Role distribution }\end{array}$ \\
Sexuality \\
Dependency on social support \\
Problems in the household \\
Leisure \& hobbles
\end{tabular}

In comparison to somatic aspects, the psychosocial aspects are more numerous and have a greater negative impact on the quality of life. Pain, obstruction of bodily functions, anxiety, depression, social withdrawal and also sometimes social isolation are the main concerns of the patients. Therefore, would it be appropriate to leave therapy to medical doctors alone ? In answering this question, one should consider that there should be no claim to sole rights in chronic disease treatment. There should be interdisciplinary cooperation! In the German speaking countries, this cooperation is far from being regularly established, but you can find a few good examples in the comprehensive treatment of rheumatic patients.

When should psychological co-therapy be provided ? Are there any criteria ? Psycho- social support becomes more important when the course of the disease is characterized by the following criteria :

1. The pain has an afflicting character and will become a main burden.

2. The pain is evidently disconnected from a somatic substrate, e.g. pathology and pain behavior are independent of each other.

3. The pathogenetically orientated and goal orientated somatic therapy does not bring any satisfying pain reduction.

4. The possibility of reducing analgesic or antirheumatic drug consumption does exist.

5. Problematic behavior in the sense of drug abuse or "medical shopping" is present.

6. The patient is unsuited for or unwilling to use therapeutic strategies.

The aim of this paper is to give an overview of the numerous possibilities available to clinical psychologists with the aim of helping RA-patients. This therapy which should complement medical treatment can be systematized into two main parts: (1) to better inform and educate patients about their illness as well as its consequences and (2) to provide psychotherapeutic support when necessary.

Some aspects and problems of patient information and education programs will first be described. After that, an overview of several selected psychotherapeutic strategies which have been applied to RA-patients will be presented. Thirdly, a comprehensive therapeutic program designed to significantly reduce pain and modify maladjusted illness behavior will be described and evaluated on the basis of empirical results.

\section{Informing and Educating the Patient}

When RA-patients are informed about their illness, the therapist should provide information about the syndrome's cause, course and prognosis. They should give practical life counselling and consultation. But they should also give emotional support corresponding to the patient's 
present disease activity level as well as to the expected consequences of the disease. Thus, the patients have to be helped to help themselves and encouraged to take responsibility for their own health.

Langer \& Birth (1987) asked 363 RA-patients what they wanted to know about their disease. Seventy-four percent of them stated that - being not well informed about their arthritis - they wanted more information about potential individual-specific causes, social consequences as well as advice pertaining to their judicial and social welfare.

\section{Most patient information and education} programs are provided as an ambulatory service within the particular ambulatory groups. The quality of these programs varies considerably. Matussek (1989) analyzed 12 studies on information and education programs available to patients. According to this analysis, qualified programs do discuss the symptomatology, the course and the pathophysiology of the special syndrome. Therapeutic aspects, such as drugs effects, ergotherapeutic exercises, relaxation, psychotherapy, functional motoric excesses and the pros and cons of special diets are also discussed. Modalities of communication between patients and therapeutic teams, institutional help for mastering psychosocial problems (change of school or working place) and/or judicial problems (insurance, questions of disablement) are also emphasized in well qualified programs.

Such programs should last about three hours and should be performed in groups of eight to ten patients in cooperation with doctors, psychologists and physical therapists. Often, it is important to enlist a social worker for information about judicial and social welfare questions.

In summary, patient information and education programs help provide not only better disease-specific knowledge, but also better adjusted illness-behavior, social contacts with patients suffering from the same disease and increasing patients' compliance.

\section{Basic methodical principles of psycho- therapeutic work with patients suffering from rheumatic diseases}

In the German speaking countries, there are seven different psychotherapeutic strategies practised, which can be labelled as (1) client-centered therapy (Rogers, 1942), (2) relaxation therapy, (3) imagination/visualisation strategies, (4) hypnosis, (5) biofeedback, (6) behavioral pain coping strategies and (7) cognitive-behavioral strategies. The two Amrican studies which used a client-centered strategy (Udelman \& Udelman, 1977 ; Kaplan \& Kozin, 1981) as the only psychotherapeutic method did not bring substantial gains in the modification of patients' pain perception and illness behavior, although the opportunity to speak with someone is helpful and attractive for many patients. In summary, there is no satisfactory empirical evidence that symptomatology and pain behavior can be modified by verbal psychotherapy alone.

If relaxation is defined as an integrative hypothalamic response, leading to a generalized reduction of the activity of the sympathetic nervous system and simultaneous increment of the activity of the parasympathetic nervous system, then it will be understood that relaxation protects the body against stress being an antagonistic response to the fight-and-flight reaction. There is a tonic and a phasic stage of relaxation. Both stages are realized at three levels :

1. A physiological level - relaxation is characterized by reduced respiration, heart rhythm, bloodpressure and muscle tension.

2. A cognitive level which can be described as the dissociation of the mind, reduced cognitive processing and especially drowsiness. 
3. A spiritual level characterized by wellbeing, well-balancedness and being of harmonious nature.

There is a broad spectrum of relaxation methods. Each has a theoretical foundation and is qualitatively distinct. The methods which are often used in German speaking countries are summarized in table 2 .

\begin{tabular}{|c|c|c|}
\hline METHOD & AUTHOR & COMAENTS \\
\hline $\begin{array}{l}\text { Progressive } \\
\text { muscle } \\
\text { relaxation }\end{array}$ & $\begin{array}{l}\text { Jacobson } \\
(1938)\end{array}$ & $\begin{array}{l}\text { Relaxation is obtained } \\
\text { by tension/relaxation } \\
\text { sensation in specific } \\
\text { muscle groups }\end{array}$ \\
\hline $\begin{array}{l}\text { Autogenic } \\
\text { training }\end{array}$ & $\begin{array}{l}\text { Schultz } \\
\text { (1932) }\end{array}$ & $\begin{array}{l}\text { Relaxation is obtained } \\
\text { by concentrating on } \\
\text { specific imagery }\end{array}$ \\
\hline Read's training & $\begin{array}{l}\text { Read } \\
(1956)\end{array}$ & $\begin{array}{l}\text { Relaxation is reached } \\
\text { by special gymnastics } \\
\text { \& breathing exercises }\end{array}$ \\
\hline Eutonia & $\begin{array}{l}\text { Alexander } \\
(1976)\end{array}$ & $\begin{array}{l}\text { Education in optimal } \\
\text { bodily tension or } \\
\text { balance }\end{array}$ \\
\hline $\begin{array}{l}\text { Functional } \\
\text { relaxation }\end{array}$ & $\begin{array}{l}\text { Fuchs } \\
\text { (1984) }\end{array}$ & $\begin{array}{l}\text { A relaxation state is } \\
\text { reached by observation } \\
\text { and control of breathing } \\
\text { rhythm }\end{array}$ \\
\hline $\begin{array}{l}\text { Gradual active } \\
\text { hypnosis }\end{array}$ & $\begin{array}{l}\text { Kretsch- } \\
\operatorname{mar} \\
(1979)\end{array}$ & $\begin{array}{l}\text { Change from autogenic } \\
\text { training to hypnosis }\end{array}$ \\
\hline $\begin{array}{l}\text { Active tonus } \\
\text { regulation }\end{array}$ & $\begin{array}{l}\text { Stokvis } \\
\text { (1959) }\end{array}$ & $\begin{array}{l}\text { No bodily relaxation } \\
\text { or reflection instead } \\
\text { concentration on } 111 \\
\text { bodyregions }\end{array}$ \\
\hline $\begin{array}{l}\text { Meditation } \\
\text { techniques }\end{array}$ & & $\begin{array}{l}\text { examples: } \\
\text { transcendental } \\
\text { meditation } \\
\text { Yoga } \\
\text { Zen }\end{array}$ \\
\hline
\end{tabular}

The classical German method is the Autogenic Training, developed by the Berlin psychiatrist Johannes Heinrich Schultz in 1932. The basic relaxation effect can be explained from the behavioral physiological standpoint of Pavlov's classical conditioning which can be described with the following example: An individual carries a heavy bag for a relatively long time. The unconditioned reaction is the arm becoming heavy and warm. Remembering this situation during the Autogenic Training (conditioned stimulus) results in the same heavy and warm sensations in the arm as in the unconditioned reaction. Now one can speak of a conditioned reaction.

In the last 15 years, Progressive Muscle Relaxation (Jacobson, 1938) has become popular in the German speaking countries. This method is easier and quicker to learn than Autogenic Training. Therefore, Progressive Muscle Relaxation is useful in the context clinical practice. The procedure of Progressive Muscle Relaxation is the following: Special muscle groups are tensed for about three seconds. After that, the patients are instructed to modify the tension slowly by reducing it as much as possible for about ten seconds. During this phase, the patient will perceive warmth and heaviness.

In the very beginning of a complex therapeutic program, one of the above mentioned relaxation trainings should be taught in order to reduce pain related tension and calm sympathetic functions. During the Progressive Muscle Relaxation training process, the patient should primarily attend to his or her breathing, giving his or her voluntary muscle tension little attention. In the beginning, often the opposite effects can be seen, so that it would not be realistic to expect a substantial pain reduction. The time required to reach optimal relaxation will, however, be continuously decreasing. Defining an individual cue for training occasions is often useful. For example, a patient could place red dots in frequented locations (e. g. bathroom, kitchen, writing desk or car).

During the last six years, there has been a boom in the application of imagery in psychotherapeutic work with rheumatic pain patients. There is some confusion between imaginative and visualizing techniques presented in the literature. Often, the term "visualisation" is used when sensory contents (visual, auditory, olfactoric and tactile) are reflected. In opposite to that the term "imagination" is applied when cognitive, emotional or social situations or events are referred to.

These methods are also well-known in psycho-analytic procedures. The Swiss psychiatrist, Carl Gustav Jung (1954) has applied 
imaginative methods within his Complex Psychotherapy. Also, the German Karl Leuner (1985) uses imaginative methods within the Katathymic Picture Experience. But all in-vivo techniques in behavior therapy do also use imagination. The most well-known methods are the Systematic Desensitization, developed by Wolpe (1974) and the several covert techniques, developed mainly by Cautela (1973).

If imaginative/visualizing techniques are applied, only imagery contents should be used which lead to positive emotions. If the imagery or visualization causes anxiety or depression, the patient should request a different imagery scene. In the case that negative imagery must be used, the imagery procedure should be ended with positive imagery. There is also a broad spectrum of different imaginative techniques, which can be classified as procedures working with pain-incompatible imagery and procedures working with transformation of imagery. In table 3 , some more details are given.

Table 3 Classification of several imagination procedures

\begin{tabular}{|c|c|c|}
\hline $\begin{array}{l}\text { CATEGORIES } \& \\
\text { SUBCATEGORIES }\end{array}$ & DESCRIPTION & EXAMPI.E \\
\hline $\begin{array}{l}\text { Pain- } \\
\text { Incompatible } \\
\text { imagery: } \\
\text { emotional }\end{array}$ & $\begin{array}{l}\text { Imagining different } \\
\text { emotions (e.g; anger, } \\
\text { assertiveness), which } \\
\text { are incompatible with } \\
\text { paln }\end{array}$ & $\begin{array}{l}\text { Imagining a date } \\
\text { with an attractive } \\
\text { partner and } \\
\text { expecting a } \\
\text { successful result }\end{array}$ \\
\hline $\begin{array}{l}\text { Pain- } \\
\text { incompatible } \\
\text { imagery: } \\
\text { sensoric }\end{array}$ & $\begin{array}{l}\text { Focusing on visual, } \\
\text { acoustic or other } \\
\text { perception, which } \\
\text { are incompatible } \\
\text { with pain }\end{array}$ & $\begin{array}{l}\text { Imagining a walk } \\
\text { or an alpine ski } \\
\text { tour during a cold } \\
\text { winter day }\end{array}$ \\
\hline $\begin{array}{l}\text { Transforming } \\
\text { imagery: } \\
\text { chaning the } \\
\text { context }\end{array}$ & $\begin{array}{l}\text { The context, which } \\
\text { is connected with } \\
\text { pain, is changed by } \\
\text { Imagery }\end{array}$ & $\begin{array}{l}\text { Ischemic pain: } \\
\text { being a spy with a } \\
\text { bullet wound in } \\
\text { arm, who is } \\
\text { pursued by } \\
\text { enemies }\end{array}$ \\
\hline $\begin{array}{l}\text { Transforming } \\
\text { imagery: } \\
\text { changing the } \\
\text { pain stimulus }\end{array}$ & $\begin{array}{l}\text { Imagining the } \\
\text { triggered pain } \\
\text { situation }\end{array}$ & $\begin{array}{l}\text { Headache: 1magining } \\
\text { steel bands around } \\
\text { the head, which are } \\
\text { then loosened }\end{array}$ \\
\hline $\begin{array}{l}\text { Transforming } \\
\text { imagery: } \\
\text { changing the } \\
\text { reaction }\end{array}$ & $\begin{array}{l}\text { Ignore the pain per- } \\
\text { ception and focusing } \\
\text { on elements of } \\
\text { perception which are } \\
\text { unconnected with pain }\end{array}$ & $\begin{array}{l}\text { Differentiating } \\
\text { between pain } \\
\text { perception and } \\
\text { coldness perception } \\
\text { and focusing only } \\
\text { on the coldness } \\
\text { perception }\end{array}$ \\
\hline
\end{tabular}

Each of these five techniques has its own indication. Characteristics of the patient's personality should also be considered. For example, it would probably be helpful for a strong male patient to cope with his chronic pain by imagining that he was an Apache Indian who was taught to ignore his pain. Thus the context of the pain is changed for the patient.

Sensoric Imagery seems to reduce acute pain attacks while transforming imagery seems to help cope with generalized non-specific chronic pain. However, there are also a lot of individual differences, which further demonstrate the psychological dimension in the evaluation of pain therapy.

Hypnosis is one of the oldest psychotherapeutic methods. In the last twenty years, there have been impressive developments in the use of hypnosis for pain therapy, resulting largely from the research of Erickson \& Rossi (1981). Hoppe (1986) differentiates between 4 kinds of pain-related hypnosis :

1. The therapist repeatedly suggests the alleviation of pain while the patient is in a passive state of hypnosis.

2. While the patient is in a hypnotic state he or she is instructed to use self-hypnosis and suggestions as coping techniques.

3. During hypnosis, the therapist provides the patient with insights related to psychological determinations of pain. Psychological

Table 4 Effective hypnotic techniques for mastering pain

\begin{tabular}{ll} 
TECHNIQUES & EXAMPLES/COMMENTS \\
\hline $\begin{array}{l}\text { Permissive, } \\
\text { indirected } \\
\text { hypnotic } \\
\text { suggestions }\end{array}$ & $\begin{array}{l}\text { "Perhaps you are perceivinge } \\
\text { youry little modification in } \\
\text { feels furry (or light, cold etc.)" }\end{array}$ \\
\hline $\begin{array}{l}\text { Macro-Sugges- } \\
\text { tions }\end{array}$ & $\begin{array}{l}\text { These can be therapeutic anecdotes } \\
\text { or metaphors. The therapeutic } \\
\text { suggestion } 1 \text { s given to trigger } \\
\text { dissociative processes of searching. }\end{array}$ \\
\hline $\begin{array}{l}\text { Suggestions, } \\
\text { which include } \\
\text { processes of } \\
\text { imaginations }\end{array}$ & $\begin{array}{l}\text { Hypnotic removal of pain: From } \\
\text { breast or stomach to the hand }\end{array}$ \\
$\begin{array}{l}\text { Hypnotic time-dissociation: } \\
\text { Transforming the pain to periods } \\
\text { which are characterized as less } \\
\text { painful }\end{array}$ \\
$\begin{array}{l}\text { Hypnotic space-dissociation: } \\
\text { Transforming the pain to places } \\
\text { which are characterized as less } \\
\text { peinful }\end{array}$
\end{tabular}


determinants can be, for example, threats, marital problems or sexual difficulties.

4. Psychodynamic strategies focus on traumatic experiences. These can be, for example, chronic suppressed frustrations stemming from childhood or rape.

Hoppe (1986) could demonstrate empirically that three distinct hypnotic techniques are most effective for mastering chronic pain. Macrosuggestions using therapeutic anecdotes from the Arabian literature (Peseschkian, 1985) seem to be the most effective in clinical practice. They do not only intend to reduce the pain intensity, but also to modify the pain behavior and promote therapeutic change.

Behavioral therapists offer biofeedback as an effective method. The most common technique is temperature biofeedback of inflamed joints which can result in a substantial pain reduction. If temperature biofeedback is combined with relaxation training and imagery, a significant decrease of pain intensity and increase in daily activities may be obtained within a period of 12 sessions. This was demonstrated in a study conducted by Anderson et al. (1985). In addition to temperature biofeedback, EMG biofeedback is especially used by patients suffering from fibromyalgic syndrome. Practically-orientated reviews are provided by Kröner-Herweg \& Sachse (1988) and Zeier (1990).

In summary, it is unknown how and why biofeedback works. Therefore, therapists are sometimes sceptical of its use. It can be assumed that the patient's ability to learn how to control his or her illness and pain is what helps. Several authors (see Achterberg et al., 1989) postulate that cognitive mechanisms make biofeedback effective. By the way, biofeedback is an optimal method of training the somatosensoric perception. This proves especially helpful for those patients who are technically orientated and dislike trusting their own subje- ctive experiences.

Common to behavioral methods is the assumption that learning processes lead to chronification. The three most important models can be differentiated (see table 5).

Table 5 Behavioral pain models

\begin{tabular}{|c|c|c|}
\hline $\begin{array}{r}\text { Model/ } \\
\text { Paradigm }\end{array}$ & Examples & Therapeutic possibilities \\
\hline Operant Model & $\begin{array}{l}\text { Pain behavior } \\
\text { is reinforced } \\
\text { by reward, by } \\
\text { avoidance of } \\
\text { disliked } \\
\text { activities, } \\
\text { by time out } \\
\text { or by praise }\end{array}$ & $\begin{array}{l}\text { Self-control- } \\
\text { techniques. } \\
\text { (e.g.stimulus control, } \\
\text { response-prevention); } \\
\text { Contract management } \\
\text { (e.g. pain cocktail, } \\
\text { motoric \& social } \\
\text { activities) }\end{array}$ \\
\hline $\begin{array}{l}\text { Respondent \& } \\
\text { interactional } \\
\text { learning }\end{array}$ & $\begin{array}{l}\text { Chronic pain } \\
\text { patients } \\
\text { develop anxiety } \\
\text { of pain attacks } \\
\text { and avold } \\
\text { many activities }\end{array}$ & $\begin{array}{l}\text { Systematic } \\
\text { desensitization in } \\
\text { vivo and also in } \\
\text { vitro }\end{array}$ \\
\hline Model learning & $\begin{array}{l}\text { Statistically } \\
\text { significant, } \\
\text { pain problems } \\
\text { are greater } \\
\text { in so-called } \\
\text { painfamilies }\end{array}$ & $\begin{array}{l}\text { Vicarious learning } \\
\text { by children; } \\
\text { video-demonstration }\end{array}$ \\
\hline
\end{tabular}

The operant model developed by Fordyce $(1976,1988)$ postulates that objective, observable pain behavior is controlled by its consequences. There are two examples. (1) Patients will consume more medication if their request for medication is always fulfilled and (2) the progressive reduction of activities - especially social withdrawal - results from the chronicity of pain. Many RA patients develop a phobic pain reaction. This anxiety is not operantly but rather respondently conditioned, representing the Pavlovian model. The third model is established by model learning. Here, the expression of pain may be fostered by significant others. Model learning plays an important role in so-called pain families. However, our knowledge in this area is very limited.

Summing up, the behavioral view of pain examines relevant characteristics of chronic pain. These techniques are best suited for in-patients.

Cognitive behavioral methods focus on the inability of patients to conceive his or her pain as manageable, due to their negative expecta- 
tions and low hopes in their ability to successfully master their pain. This inability may result in helplessness, hopelessness and inactivity. There is a system-inherent weakness in the classificability of the many therapeutic techniques, so cognitive therapists endeavoured to develop individual tailored psychotherapeutic strategies (see Flor \& Turk, 1990). Three main methods of intervention are differentiated in table 6 .

Table 6 Classification of several cognitive pain coping procedures

\begin{tabular}{|c|c|c|}
\hline Categories & Description & Example \\
\hline $\begin{array}{l}\text { Self-Instruc- } \\
\text { tion }\end{array}$ & $\begin{array}{l}\text { Stress-inoculation: } \\
\text { prevention against } \\
\text { being overwhelmed } \\
\text { by pain }\end{array}$ & $\begin{array}{l}\text { "I expect that } \\
\text { the pain will } \\
\text { become worse, but } \\
\text { I will try to } \\
\text { hold out." }\end{array}$ \\
\hline \multirow[t]{2}{*}{$\begin{array}{l}\text { Strategies } \\
\text { for changing } \\
\text { the meaning }\end{array}$} & $\begin{array}{l}\text { Denial: Self- } \\
\text { instruction to } \\
\text { deny the mode } \\
\text { of pain }\end{array}$ & $\begin{array}{l}\text { Imagining painful } \\
\text { morning stiffness } \\
\text { as necessary to } \\
\text { rest the joins }\end{array}$ \\
\hline & $\begin{array}{l}\text { Rationalization: } \\
\text { Self-instruction } \\
\text { to think only about } \\
\text { the positive } \\
\text { aspects of pain }\end{array}$ & $\begin{array}{l}\text { "My pain is a } \\
\text { characteristic } \\
\text { of my excellent } \\
\text { ability of } \\
\text { interior } \\
\text { perception." }\end{array}$ \\
\hline \multirow[t]{2}{*}{$\begin{array}{l}\text { Controlling } \\
\text { the attention }\end{array}$} & $\begin{array}{l}\text { Passive diversion: } \\
\text { by external events }\end{array}$ & $\begin{array}{l}\text { Television (e.g. } \\
\text { Sports Show, } \\
\text { fascinating } \\
\text { broadcast) }\end{array}$ \\
\hline & $\begin{array}{l}\text { Active diversion: } \\
\text { by activity }\end{array}$ & $\begin{array}{l}\text { Mental arithmetic } \\
\text { during poin }\end{array}$ \\
\hline
\end{tabular}

Cognitive behavioral procedures help to reduce the pain intensity as well as depression and anxiety. Therefore, they can be seen as widely indicated for patients suffering from pain. If a cost-benefit-analysis of several psychotherapeutic strategies is to be made the following conclusions can be drawn :

1. Programs which promote better adjusted pain and disease coping result in effective and usually long-lasting pain relief.

2. Supportive group therapy was assessed by patients as helpful but did not result in pain reduction.

3. A multimethodal strategy increases the probability for a successful outcome of the psychological co-therapy by rheumatic patients.

Efficient therapeutic strategies which fulfil these suggestions are (1) teaching relaxation techniques (perhaps with the help of biofeedback), (2) providing coping strategies for paincoping, (3) teach imagery techniques and (4) provide information and discussion about disease-relevant themes.

These topics should be integrated in a modern psychological pain-therapeutic program. Rehfisch, Basler and Seemann (1989) constructed such a program which is summarized in the next section.

\section{Description of a multi-modal psycho- logical pain management program for patients suffering from rheumatic syndromes}

This program was designed and evaluated primarily for lower back pain patients (Kaluza \& Basler, 1988) but has been modified for RA patients (Rehfisch, 1988) and other rheumatic diseases such as fibrositis and spondilytis ancylosans (Basler \& Rehfisch, 1990).

The program can be applied to out-patients during a 3 month period in 12 sessions. Each contact lasts about 90 minutes. Four phono tapes are available to help consolidate the therapeutic topics. The published therapy manual is well structured and the procedure well standardized. This program has been applied to more than 200 patients and appears to be easily tailored to meet individuals' needs.

Details about the structure and the procedure of the program are the following: Four to twelve weeks before the beginning of the therapy the patients are invited to an information meeting. The therapeutic procedure is very consuming, therefore, the patients should seriously consider if they have enough time to take part in the therapy. The patients have to keep a pain diary for 14 days. This provides information about pain-characteristics, injuries, daily mood, drug consumption and frequency of pain coping. It is important that the patient does his homework and carefully records his pain episodes throughout the course of the 
therapy.

A detailed psychodiagnostic interview should be made two weeks before starting the therapy. It helps to gain information about depression, anxiety, complaints and other information about the pain. Patients with low pain intensity do not profit from this program, probably because their compliance is not good. Rheumatic patients with moderate to severe pain profit the most from the therapy.

Taking these facts into consideration, a participation rate of more than $90 \%$ and a dropout rate smaller than $7 \%$ may be obtained.

Three typical sessions of the therapeutic program are described to give an impression of the manifold techniques and procedures of the program: The main goal of the third session is coping with relaxation difficulties. During the second session, the patients were introduced to progressive relaxation and had the opportunity to train their muscular relaxation as homework with help of a tape.

Table 7 Structure and contents of the $3 \mathrm{rd}$ session

\begin{tabular}{|c|c|c|}
\hline CONTENTS & TOPICS & GOALS \\
\hline Pain diary & $\begin{array}{l}\text { Checking the home- } \\
\text { work and the pain } \\
\text { characteristics } \\
\text { during the last } \\
\text { week }\end{array}$ & $\begin{array}{l}\text { Patients observe, } \\
\text { that pain is } \\
\text { continuous and } \\
\text { it can be } \\
\text { brought under } \\
\text { control by } \\
\text { relaxation }\end{array}$ \\
\hline $\begin{array}{l}\text { Discuss the } \\
\text { relaxytion } \\
\text { exercises done } \\
\text { at home }\end{array}$ & $\begin{array}{l}\text { Each patient } \\
\text { roports his daily } \\
\text { exercises, his ; } \\
\text { quality of rela- } \\
\text { xation; preference } \\
\text { for spocial } \\
\text { relaxation } \\
\text { circumstances }\end{array}$ & $\begin{array}{l}\text { Foundation of a } \\
\text { constructive } \\
\text { group-astmos- } \\
\text { phere and } \\
\text { group-solidari } \\
\text { zation }\end{array}$ \\
\hline $\begin{array}{l}\text { Difficulties } \\
\text { emerged during } \\
\text { relaxation } \\
\text { training }\end{array}$ & $\begin{array}{l}\text { Speaking about } \\
\text { disturbing bodily } \\
\text { sensations }\end{array}$ & $\begin{array}{l}\text { Balance of } \\
\text { autonomous } \\
\text { nervous system } \\
\text { in spite of pain }\end{array}$ \\
\hline $\begin{array}{l}\text { Training of } \\
\text { muscular } \\
\text { relaxation }\end{array}$ & $\begin{array}{l}\text { Patients exercise } \\
\text { together progressive } \\
\text { relaxation and } \\
\text { incorporate some } \\
\text { new muscle groups } \\
\text { muscle groups }\end{array}$ & $\begin{array}{l}\text { Progression in } \\
\text { relaxation, model } \\
\text { learning; } \\
\text { avoldance of } \\
\text { training } \\
\text { mistakes }\end{array}$ \\
\hline $\begin{array}{l}\text { What effect } \\
\text { has relaxation } \\
\text { on the human } \\
\text { body? }\end{array}$ & $\begin{array}{l}\text { Trainer gives } \\
\text { information about } \\
\text { neuro- and psycho- } \\
\text { physiological } \\
\text { correlates of } \\
\text { relaxation }\end{array}$ & $\begin{array}{l}\text { Education in } \\
\text { psychophysiological } \\
\text { processes of } \\
\text { rheumatic disease }\end{array}$ \\
\hline
\end{tabular}

As shown in table 7 , a detailed discussion about procedural aspects of progressive relaxation is lead by the therapist during the third session. Patients talk about any difficulties which they may have had during the home relaxation exercises. Such difficulties can be, for example, sensation of coolness, muscular tensions or external distraction. The therapist should provide suggestions or advice as well as reassure the patient that these types of difficulties are normal.

The sixth session is especially important because the patients are provided with some active pain coping strategies. This is done by focusing diversion.

Table 8 Structure and contents of the 6th session

\begin{tabular}{|c|c|c|}
\hline CONIENTS & TOPICS & GOALS \\
\hline Pain diary & $\begin{array}{l}\text { Check homework and the } \\
\text { pain characteristics } \\
\text { during the last week }\end{array}$ & $\begin{array}{l}\text { Patients observe that } \\
\text { pain is not continu- } \\
\text { ous and it can be } \\
\text { brought under control } \\
\text { by relaxation }\end{array}$ \\
\hline $\begin{array}{l}\text { Experience } \\
\text { with cue } \\
\text { "silence" }\end{array}$ & $\begin{array}{l}\text { "Silence" has different } \\
\text { meanings depending on } \\
\text { the cognitive instruc- } \\
\text { tion; patients report } \\
\text { about their individual } \\
\text { experiences with that } \\
\text { cue }\end{array}$ & $\begin{array}{l}\text { Patients learn the } \\
\text { pain-related differ- } \\
\text { ence between active } \\
\text { doing and passive } \\
\text { permiting }\end{array}$ \\
\hline $\begin{array}{l}\text { Effects of } \\
\text { diversion } \\
\text { from pain }\end{array}$ & $\begin{array}{l}\text { Collecting examples } \\
\text { which demonstrate the } \\
\text { relationship botween } \\
\text { pain-perception and } \\
\text { focusing on other } \\
\text { things during pain }\end{array}$ & $\begin{array}{l}\text { Motivating the } \\
\text { patients to handle } \\
\text { his own pain in } \\
\text { different situations }\end{array}$ \\
\hline $\begin{array}{l}\text { Going for a } \\
\text { walk fully } \\
\text { attentive }\end{array}$ & $\begin{array}{l}\text { Conscious perception } \\
\text { of one's own hand, } \\
\text { respiration, taste } \\
\text { on the tongue }\end{array}$ & $\begin{array}{l}\text { Motivating the } \\
\text { patients to focus } \\
\text { their attention on } \\
\text { perception-systems } \\
\text { other than pain } \\
\text { perception }\end{array}$ \\
\hline $\begin{array}{l}\text { Internal } \\
\text { diversion } \\
\text { from pain }\end{array}$ & $\begin{array}{l}\text { Construction of } \\
\text { pain-incompatible } \\
\text { phantasy-pictures } \\
\text { of interesting } \\
\text { context }\end{array}$ & $\begin{array}{l}\text { Changing the imagery } \\
\text { to other than } \\
\text { relaxation }\end{array}$ \\
\hline $\begin{array}{l}\text { Phantasy- } \\
\text { journey and } \\
\text { group- } \\
\text { discussion } \\
\text { about it }\end{array}$ & $\begin{array}{l}\text { Imagination of a } \\
\text { tree during the four } \\
\text { seasons; mental } \\
\text { reflections of } \\
\text { individual phantasy- } \\
\text { journeys }\end{array}$ & $\begin{array}{l}\text { Diversion from pain } \\
\text { to external, changeabl } \\
\text { things; patients gain } \\
\text { experience with changis } \\
\text { seemingly unchangeable } \\
\text { things }\end{array}$ \\
\hline
\end{tabular}

To give one example: Patients have already learned relaxation in a previous session. Relaxation can be understood as a specific form of imagery. This time, attention should be focused by means of imagination. With the help of so-called phantasy journeys, the patients concentrate on bodily and external processes, especially those things or events which are apparently unchangeable. Likewise, a parallel should be drawn to chronic pain. 
The 11th session deals with the cognitive and emotional restructuring of pain and stress related cognitions as well as preparing oneself for pain situations.

Table 9 Structure and contents of the 11 th session

\begin{tabular}{|c|c|c|}
\hline CONTENTS & TOPICS & GOALS \\
\hline Pain diary & $\begin{array}{l}\text { Check homework and } \\
\text { the pain character- } \\
\text { istics during the } \\
\text { last week }\end{array}$ & $\begin{array}{l}\text { Patients observe, } \\
\text { that pain is not } \\
\text { continuous and it } \\
\text { can be brought under } \\
\text { control by relaxation }\end{array}$ \\
\hline $\begin{array}{l}\text { Positive } \\
\text { thoughts } \\
\text { during pain } \\
\text { and stress }\end{array}$ & $\begin{array}{l}\text { Patients discuss } \\
\text { several pain- and } \\
\text { stress- situations } \\
\text { and will be able } \\
\text { to restructure them } \\
\text { in a positive way }\end{array}$ & $\begin{array}{l}\text { Patients learn to } \\
\text { reflect about advan- } \\
\text { tages of positive } \\
\text { thinking }\end{array}$ \\
\hline $\begin{array}{l}\text { Imagery- } \\
\text { training and } \\
\text { group discus- } \\
\text { sion }\end{array}$ & $\begin{array}{l}\text { Imagining pain-free } \\
\text { body-regions, } \\
\text { introduction to } \\
\text { self-hypnosis by } \\
\text { sugges-tions of } \\
\text { warmth, pain-coping, } \\
\text { etc. }\end{array}$ & $\begin{array}{l}\text { Patients with } \\
\text { difficulties in } \\
\text { learning relaxation } \\
\text { profit by special } \\
\text { pain-related coping- } \\
\text { mechanisms; } \\
\text { transformation of } \\
\text { the pain to different } \\
\text { pain-areas by } \\
\text { suggestion }\end{array}$ \\
\hline $\begin{array}{l}\text { Preparation } \\
\text { to pain- } \\
\text { situations }\end{array}$ & $\begin{array}{l}\text { Instruction- } \\
\text { training and handl- } \\
\text { Ing with situations, } \\
\text { which are related } \\
\text { to preparation for, } \\
\text { confrontation with } \\
\text { and mastering of pain }\end{array}$ & $\begin{array}{l}\text { Patients learn to } \\
\text { cope with pain- } \\
\text { s1tuation expected } \\
\text { in the future } \\
\text { n }\end{array}$ \\
\hline
\end{tabular}

Cognitive and emotional restructuring of pain can be achieved through self-hypnosis. Self-hypnosis is especially helpful for those patients who do not profit from progressive relaxation. Beyond that, the patient should learn to see pain and stress as not only negative or destructive. Pain also has a signal function. If the patient detects this and can accept it, pain perception can help him or her to modify the behavior related to pain or social relevant persons.

An example of a useful therapeutic tool is Stress Inoculation Training developed by Meichenbaum (1979) which has been adopted for use with special pain problems. Because this area is usually a topic towards the end of the therapy, it also helps to prevent the often observed deterioration of pain status after therapy.

In summary, the therapeutic program is composed of several well-defined and well-established procedures and techniques. The single components of the program are aimed at the physiological, emotional, cognitive, as well as the behavioral pain-levels of rheumatic patients.

\section{Evaluation studies of the therapeutic programs described}

Four studies were published evaluating this therapeutic concept empirically. A report of Rehfisch's study (1988) follows: 62 patients suffering from rheumatoid arthritis took part in this study. They were informed about the individual utility for them and about the aim of the study. Those who decided to participate in the therapeutic procedure were divided by chance in a treatment and a control group. Each group consisted of 31 patients with an average of 56 years of age and an average illness duration of 12 years. In each group, there were thirty female and one male subjects.

\begin{tabular}{|c|c|c|c|c|c|}
\hline GROPE & $\begin{array}{l}\text { EEFORE } \\
\text { THERAPY }\end{array}$ & $\begin{array}{l}\text { INTER- } \\
\text { VEXTIOA }\end{array}$ & $\begin{array}{l}\text { AFTER } \\
\text { THERAPY }\end{array}$ & $\begin{array}{l}\text { FOLLOW-UP } 1 \\
\text { (4 MONTHS } \\
\text { AFTER) } \\
{[\text { MP( }(3)]}\end{array}$ & $\begin{array}{l}\text { POLLOW-UP } \\
2 \\
(1 \text { YEAR } \\
\text { AFTER) } \\
{[K P(4)]}\end{array}$ \\
\hline \multirow{3}{*}{$\begin{array}{l}\text { Thera- } \\
\text { peut1c } \\
\text { croup }\end{array}$} & Interviou & Therapy & Interview & & \\
\hline & $\begin{array}{l}\text { Pain diary } \\
\text { (14 days) }\end{array}$ & Paln diary & $\begin{array}{l}\text { Pain diary } \\
\text { ( } 14 \text { days) }\end{array}$ & $\begin{array}{l}\text { Pain diary } \\
\text { (14 days) }\end{array}$ & $\begin{array}{l}\text { Pain diary } \\
\text { ( } 14 \text { days) }\end{array}$ \\
\hline & $\begin{array}{l}\text { Question- } \\
\text { nalres }\end{array}$ & $\begin{array}{l}\text { Question- } \\
\text { naires }\end{array}$ & $\begin{array}{l}\text { Question- } \\
\text { naires }\end{array}$ & $\begin{array}{l}\text { Question- } \\
\text { naires }\end{array}$ & $\begin{array}{l}\text { Question- } \\
\text { naires }\end{array}$ \\
\hline \multirow[t]{2}{*}{$\begin{array}{l}\text { Costrol } \\
\text { group }\end{array}$} & $\begin{array}{l}\text { Pain diery } \\
\text { ( } 1<\text { days })\end{array}$ & & $\begin{array}{l}\text { Pain diary } \\
\text { ( } 14 \text { days })\end{array}$ & $\begin{array}{l}\text { Pain diary } \\
\text { (14 days) }\end{array}$ & \\
\hline & $\begin{array}{l}\text { Question- } \\
\text { naires }\end{array}$ & & $\begin{array}{l}\text { Question- } \\
\text { naires }\end{array}$ & $\begin{array}{l}\text { Question- } \\
\text { naires }\end{array}$ & \\
\hline
\end{tabular}

Fig. 1 Design of the evaluation study by Rehfisch (1988). MP = measurement point.

The design of the study is described in figure 1 . In total, there were 4 measurement points. After the first follow-up, the patients of the control-group started their pain-therapeutic management. Therefore, data for the second follow-up do not exist for this group. Dependent variables were data of a pain diary (pain characteristics, handicaps, pain related mood), of questionnaires (anxiety, depression, complaints, sleep problems, total-pain, pain complaints, pain-diversion), and of interviews.

In a MANOVA, interaction between group 
Pain

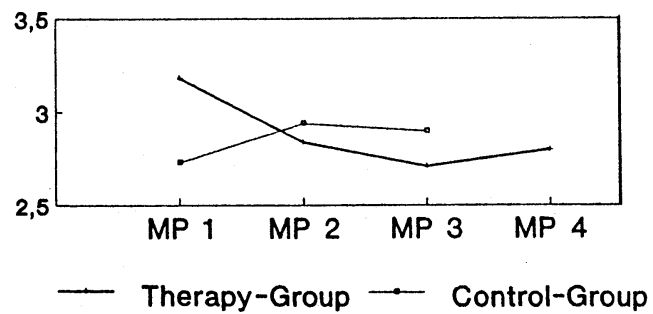

Handicaps

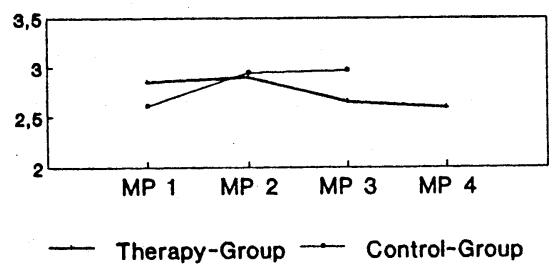

Mood

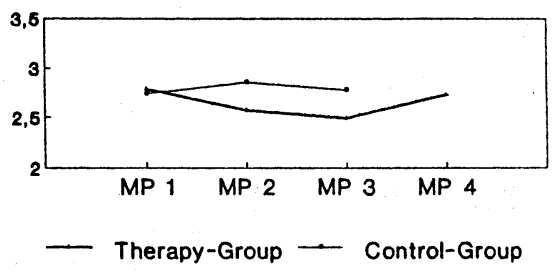

Fig. 2 Differences between therapeutic and control groups in pain, handicaps and mood during the course of psychological pain therapy (results of pain diaries).

and time was found to be statistically significant. Thus, a general positive therapeutic effect was obtained.

A detailed inspection of the pain diary results shows that at the first follow-up, which was done four months after the end of the therapy, a significant reduction of pain intensity was demonstrated (see fig. 2). Pain reduction was about 25\%. At the second follow-up, which was done one year after the end of the therapy, a $17 \%$ reduction of pain intensity was present as compared to the starting score. This difference was also found to be statistically significant. A tendency towards further improvement was also found for the handicap scale. Finally, there were no significant effects
Anxiety

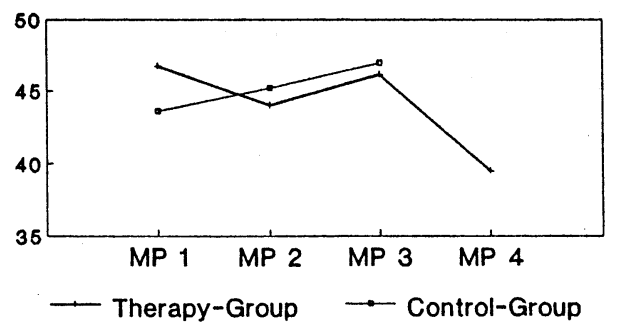

Depression

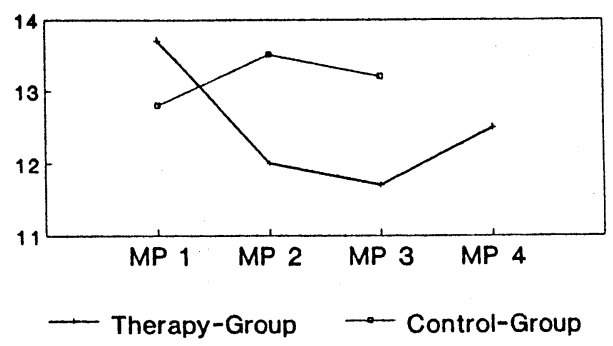

Complaints

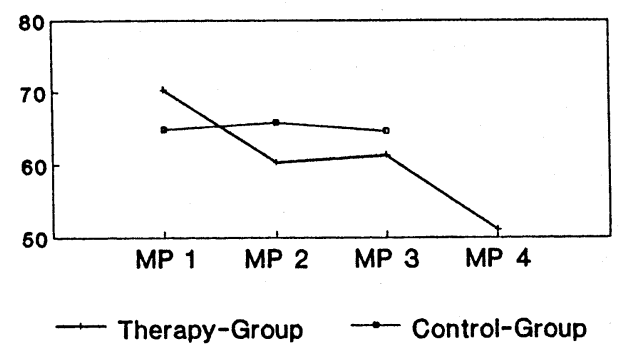

\section{Sleep-problems}

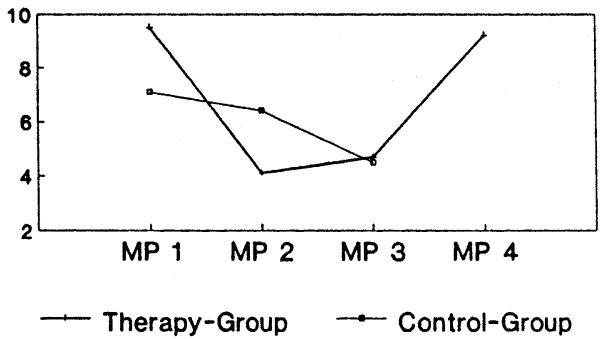

Fig. 3 Differences between therapeutic and control group in anxiety, depression, complaints and sleep problems during the course of psychological pain therapy (result of questionnaires).

found for daily mood scores.

Immediately after the end of the therapy (see fig. 3), a significant reduction in anxiety 
was found. At the first follow up there is an increase in anxiety which will be reduced again at the time of the second follow up. Initial depression scores were found to be at clinical levels for both groups. The patients of the therapeutic group reduced their depression levels during the course of therapy. These effects lasted until the second follow-up after one year. Significant and longlasting modifications in general complaints were demonstrated, even though the initial scores were higher than normal. Thus, systematic reductions were found at each of the four measurement periods. Contrastingly, the patients of the control group did not show any substantial changes. Stat-

\section{Total-pain}

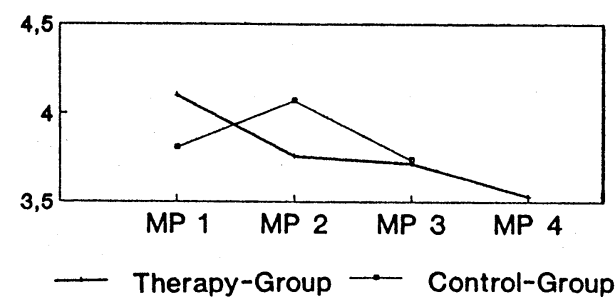

Pain-Complaints

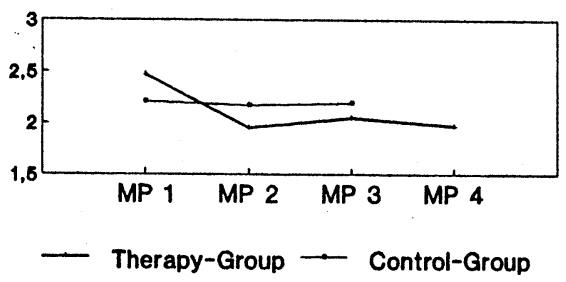

Pain-Diversion

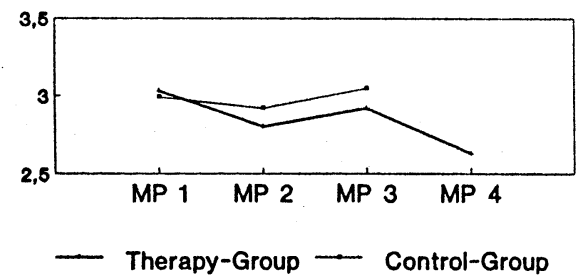

Fig. 4 Differences between therapeutic and control groups in total pain, pain-complaints and pain diversions (results from rating scales: $1=$ very good ; $6=$ very bad). istically significant improvement in sleep disturbances were found during the second and the third measurements in comparison to the first measurement. However, there is no genuine advantage for the therapeutic group because this effect was not demonstrable after one year.

Significant and longlasting modifications were demonstrated in pain related complaints. During all measurement points, statistically significant reductions could be confirmed. An essential goal of the therapy is the frequent use of diversion methods during pain states. In testing these intervention effects, there were no significant improvements in the therapeutic group during the first follow-up. But there was a statistically significant effect during the second follow-up after one year.

Immediately after the therapy and also one year later, patients were asked to rate their individual therapeutic successes. Patients reported improvements in their general state of health, better pain coping, better adjusted pain attitude and better ability to relax. Patients also rated their ability to reduce actual light (daily) pain with help of relaxation or imagination. Ratings were done during the second and forth measurement points.

Immediately at the end of the therapy patients reported very good, good and satisfactory improvements in pain reduction. One year after the therapy, you can see a small shift to the right side. But still only one out of 31 patients reported no improvement.

For severe pain states, very different results were found. During measurement 2, four patients (or 16\%) reported good or very good pain reduction. Four persons reported insufficient pain coping. So, depending on the pain intensity, patients differ considerably in their abilities to handle pain. But most of the patients do profit from the therapeutic program in a moderate way. 
Almost all patients gave positive ratings to the pain program described and recommended it to their fellow patients. Such very good estimations were given in the first as well as in the second follow-up. Group effects are rated positively, but the therapy's usefulness was interpreted to decline over time after cessation of therapy.

What are the critical points according to patient's reports?

1. Some patients expected too great a reduction in pain intensity.

2. Some patients used the group as a possibility to win closer social contacts, this having been an area of disappointment for some patients.

All in all, almost all patients should profit by a psychological pain therapy. But it should be noticed that about $33 \%$ reported minimal success one year after the therapy. These patients had mild pain, so that their compliance during the therapy and afterwards was low. The larger part of patients who profited from the therapy applied the techniques daily or weekly. However, only one in five patients used the pain coping techniques during severe pain states. In this case, medical therapy is necessary. Thus, pain is a dialectical problem which requires interdisciplinary attention.

\section{References}

Achterberg, J., Kenner, C. \& Casey, D. 1989 Behavioral strategies for the reduction of pain and anxiety associated with orthopedic trauma. Biofeedback Self-Regul., 14, 101114.

Alexander, G. 1976 Eutonie. München : Kösel.

Anderson, K. O., Bradley, L. A., Young, L. D., McDaniel, L. K. \& Wise, C. M. 1985 Rheumatoid arthritis: Review of psychological factors related to etiology, effect and treatment. Psychol. Bull., 98, 258-387.

Basler, H. -D. \& Rehfisch, H. P. 1989 Psy- chologische Schmerztherapie in Rheuma-LigaSelbsthilfegruppen. Z. Klin. Psychol., 18, 203-214.

Cautela, J. 1973 Covert processes and behaviour modification. J. Nerv. Ment. Dis., 157, 2735.

Erickson, M. H. \& Rossi, E. L. 1981 Hypnotherapie. Aufbau-Beispiele-Forschugen.

München : Pfeiffer.

Flor, H. \& Turk, D. C. 1990 Der kognitivverhaltenstherapeutische Ansatz und seine Anwendung. In H. -D. Basler, C. Franz, B. Kröner-Herwig, H. P. Rehfisch \& H. Seemann (Eds.) Psychologische Schmerztherapie.

Berlin: Springer, Pp. 501-518.

Fordyce, W. E. 1976 Behavioral concepts in chronic pain and illness. St. Louis: Mosby.

Fordyce, W. E. 1988 Pain and suffering: A reappraisal. Am. Psychol., 43, 276-283.

Fuchs, M. 1984 Funktionelle Entspannung. Theorie und Praxis einer organismischen Entpsannung über den rhythmisierten Atem. Stuttgart : Hippokrates.

Hoppe, F. 1986 Direkte und indirekte Suggestionen in der hypnotischen Beeinflussung chronisher Schmerzen. Frankfurt/Main:

Lang.

Jacobson, E. 1938 Progressive relaxation. Chicago: University of Chicago Press.

Jung, C. G. 1954 Von den Wurzeln des Bewußtseins. Zürich: Rascher.

Kaluza, G. \& Basler, H. -D. 1988 Gruppenbehandlung von Patienten mit chronischen Rückenschmerzen - eine Untersuchung in allgemeinärztlichen Praxen. In W. Schüffel (Ed.) Sich gesund fühlen im Jahr 2000. Berlin : Springer, Pp. 266-284.

Kaplan, S. \& Kozin, F. 1981 A controlled study of group counseling in rheumatoid arthritis. $J$. Rheumatol., 8, 91-99.

Kretschmer, E. 1946 Über gestufte Aktivhypnose und den Umbau der Hypnosetechnik. Dtsch. Med. Wochenschr., 71, 281-283. 
Kröner-Herwing, B. \& Sachse, R. 1988 Biofeedbacktherapie. Suttgart: Kohlhammer.

Langer, H. E. \& Birth, U. 1987 Probleme und Interessenschwerpunkte von Rheumapatienten und Planung von Patienteninformationen. Rheuma, 6, 7-16.

Leuner, K. 1985 Lehrbuch des Katathymen Bilderlebens. Bern: Huber.

Matussek, S. 1989 Aufklärungs- und Informationsprogramme für Rheumapatienten. In $\mathrm{H}$. P. Rehfisch, H. D. Basler \& H. Seemann (Eds.) Psychologische Schmerzbehandlung bei Rheuma. Berlin: Springer, Pp. 38-53.

Meichenbaum, D. W. 1979 Kognitive Verhaltensmodifikation. München: Urban \& Schwarzenberg.

Peseschkian, N. 1985 Der Kaufmann und der Papagei. Frankfurt/Main : Fischer.

Raspe, H. H. 1989 Chronische Polyarthritis und ankylosierende Spondylitis. In H. P. Rehfisch, H. -D. Basler, \& H. Seemann (Eds.) Psychologische Schmerzbehandlung bei Rheuma. Berlin : Springer, Pp. 15-26.

Read, G. D. 1956 Der Weg zur natürlichen Geburt. Hamburg.

Rahfisch, H. P. 1986 Psychologische Schmerztherapie bei Patienten mit chronischer Polyarthritis. Vortrag, 22. Tagung der Deutschen Gesellschaft für Rheumatologie vom 30. 10. -4. 11. 1986, Freiburg.
Rehfisch, H. P. 1988 Psychologische Schmerztherapie bei chronischer Polyarthritis. Eine kontrollierte Studie. Aktuelle Rheumatol., 13, $34-37$.

Rehfisch, H. P. \& Basler, H. -D. 1989 Kognitive Verhaltenstherapie bei Patienten mit ankylosierender Spondelytis. Z. Rheumatol., 48, 79-85.

Rehfisch, H. P., Basler, H. -D., Seemann, H. (Eds.) 1989 Psychologische Schmerzbehandlung bei Rheuma. Berlin: Springer.

Rogers, C. 1942 Client-centered Therapy. Boston: Houghton Mifflin Comp.

Schultz, J. H. 1932 Das Autogene Training. Stuttgart: Thieme.

Stokvis, B. 1959 Aktive Tonusregulation als Entspannungstherapie. Z. Psychother. Med. Psychol., 9.

Udelman, H. D. \& Udelman, D. L. 1977 Team therapy in a rheumatology unit. Psychosomatic, $18,42-46$.

Verband Deutscher Rentenversicherungsträger (Ed.) 1984 VDR Statistik Rehabilitation des Jahres 1983. Band 64. Würzburg: Stürtz AG.

Wolpe, J. 1974 Praxis der Verhaltenstherapie. Bern: Huber.

Zeier, H. 1990 Biofeedback. Bern: Huber. 